\title{
Synergistic Recapturing of External and Internal Phosphorus for In Situ Eutrophication Mitigation
}

\author{
Minmin Pan ${ }^{1,2,3}$, Tao Lyu ${ }^{4,5, *(\mathbb{D})}$, Meiyi Zhang ${ }^{1} \mathbb{C}^{(}$, Honggang Zhang ${ }^{1}$, Lei Bi ${ }^{1}$, Lei Wang ${ }^{1}(\mathbb{D}$, \\ Jun Chen ${ }^{1}$, Chongchao Yao ${ }^{1}$, Jafar Ali ${ }^{1} \mathbb{D}$, Samantha Best ${ }^{4,5}$, Nicholas Ray ${ }^{4,5} \mathbb{D}$ and \\ Gang Pan 1,2,4,5,*
}

1 Research Center for Eco-Environmental Sciences, Chinese Academy of Sciences, Beijing 100085, China; panminmin@hotmail.com (M.P.); myzhang@rcees.ac.cn (M.Z.); hgzhang@rcees.ac.cn (H.Z.); leibi@rcees.ac.cn (L.B.); leiwang@rcees.ac.cn (L.W.); chenjunzhl@126.com (J.C.); ancico@126.com (C.Y.); jafaraliqau@gmail.com (J.A.)

2 Sino-Danish College of University of Chinese Academy of Sciences, Beijing 100049, China

3 Department of Environmental Engineering, Technical University of Denmark, DK-2899 Lyngby, Denmark

4 School of Animal, Rural, and Environmental Sciences, Nottingham Trent University, Brackenhurst Campus, Nottingham NG25 0QF, UK; samantha.best02@ntu.ac.uk (S.B.); nicholas.ray@ntu.ac.uk (N.R.)

5 Centre of Integrated Water-Energy-Food Studies (iWEF), Nottingham Trent University, Nottinghamshire, Nottingham NG25 0QF, UK

* Correspondence: tao.lyu@ntu.ac.uk (T.L.); gang.pan@ntu.ac.uk or gpan@rcees.ac.cn (G.P.); Tel.: +44-115-848-5296 (T.L.); +44-0115-848-5348 (G.P.)

Received: 30 November 2019; Accepted: 16 December 2019; Published: 18 December 2019

\begin{abstract}
In eutrophication management, many phosphorus $(\mathrm{P})$ adsorbents have been developed to capture $\mathrm{P}$ at the laboratory scale. Existing $\mathrm{P}$ removal practice in freshwaters is limited due to the lack of assessment of the possibility and feasibility of controlling P level towards a very low level (such as $10 \mu \mathrm{g} / \mathrm{L}$ ) in order to prevent the harmful algal blooms. In this study, a combined external and internal $\mathrm{P}$ control approach was evaluated in a simulated pilot-scale river-lake system. In total, $0.8 \mathrm{~m}^{3}$ of simulated river water was continuously supplied to be initially treated by a $\mathrm{P}$ adsorption column filled with a granulated lanthanum/aluminium hydroxide composite (LAH) $P$ adsorbent. At the outlet of the column (i.e., inlet of the receiving tanks), the $\mathrm{P}$ concentration decreased from 230 to $20 \mu \mathrm{g} / \mathrm{L}$ at a flow rate of $57 \mathrm{~L} /$ day with a hydraulic loading rate of $45 \mathrm{~m} /$ day. In the receiving tanks (simulated lake), $90 \mathrm{~g}$ of the same adsorbent material was added into $1 \mathrm{~m}^{3}$ water for further in situ treatment, which reduced and maintained the $P$ concentration at $10 \mu \mathrm{g} / \mathrm{L}$ for 5 days. The synergy of external and internal $P$ recapture was demonstrated to be an effective strategy for maintaining the $\mathrm{P}$ concentration below $10 \mu \mathrm{g} / \mathrm{L}$ under low levels of $\mathrm{P}$ water input. The $\mathrm{P}$ removal was not significantly affected by temperature $\left(5-30^{\circ} \mathrm{C}\right)$, and the treatment did not substantially alter the water $\mathrm{pH}$. Along with the superior $\mathrm{P}$ adsorption capacity, less usage of LAH could lead to reduced cost for potation eutrophication control compared with other widely used P adsorbents.
\end{abstract}

Keywords: eutrophication control; phosphorus recapturing; lake restoration; phosphorus adsorbent

\section{Introduction}

Phosphorus $(\mathrm{P})$, largely derived from phosphate rock, is an essential nutrient for crop growth and hence for global food supply [1]. However, global P reserves are dramatically depleting due to the increasing demand for P-based agricultural fertilizers [2]. After the application of fertilizer to agricultural soils, substantial amounts of $\mathrm{P}$ can run away from agricultural land and enter natural waters, causing eutrophication, where harmful algal blooms (HABs), death of fish, degradation of aquatic macrophytes, and water quality deterioration are likely to occur [3]. Therefore, $P$ removal and 
recovery from surface waters is one of the most important, yet difficult objectives for eutrophication control [4].

There is no consensus yet on the threshold of $\mathrm{P}$ concentration for preventing eutrophication in natural waters, even though many studies have concluded the concentration of $100 \mu \mathrm{g} \mathrm{P} / \mathrm{L}$ to be too high $[5,6]$. Various methods, such as constructed wetland systems, have been applied in attempts to remove $\mathrm{P}$ and safeguard rivers [7]. P concentrations can be reduced from the $4.5-19.7 \mathrm{mg} / \mathrm{L}$ level to around $23 \mu \mathrm{g} / \mathrm{L}$ before entering surface waters by means of such wetlands, [8]. However, recent studies show that HABs could happen even at P levels as low as of $30 \mu \mathrm{g} / \mathrm{L}$ [9]. The strictest regulation of $\mathrm{P}$ concentration for lakes and reservoirs has been set down by the US Environmental Protection Agency as $10 \mu \mathrm{g} \mathrm{P} / \mathrm{L}$ [10]. Thus, the development of an effective approach to achieve ultra-low concentrations of $\mathrm{P}$ is needed.

P removal techniques can be generally classified into physical, biological, and chemical methods. A combination of these methods has been reported to achieve less than $100 \mu \mathrm{g} \mathrm{P} / \mathrm{L}$ [11], and sometimes even lower than $10 \mu \mathrm{g} \mathrm{P} / \mathrm{L}$ [12]. Among these methods, P adsorption has been recognized as a promising technology for reaching such low P concentrations [13]. Many P adsorbents derived from natural minerals and biochars are not desirable because they are usually associated with high equilibrium $P$ concentration at zero net $\mathrm{P}$ sorption $\left(\mathrm{EPC}_{0}\right)$ due to negatively bound $\mathrm{P}[14,15]$. Industrial byproducts used as $\mathrm{P}$ adsorbents are cheap; however, their application often alters the $\mathrm{pH}$ of the water and produce adverse effects [16]. Thus, synthetic P adsorbents such as Phoslock ${ }^{\circledR}$ [17] have received growing attention, as their characteristics can be manipulated in order to maximize the $\mathrm{P}$ adsorption ability (Table 1). Even though Phoslock ${ }^{\circledR}$ has been used for P removal in lakes, a relatively high solid dosage of 200:1 Phoslock:P weight ratio is necessary to reach the desired levels of less than $10 \mu \mathrm{g} P / \mathrm{L}$ [18]. Nevertheless, there is a demand for a highly efficient $\mathrm{P}$ adsorbent that can control P levels of natural waters at around $10 \mu \mathrm{g} / \mathrm{L}$.

Table 1. The material-based phosphorous adsorbent categories and their adsorption capacities.

\begin{tabular}{ccc}
\hline Category & \multicolumn{1}{c}{ Name } & Adsorption Capacity (mg P/g) \\
\hline \multirow{3}{*}{ Natural materials } & Soil or sands & $4.2-5.8[19]$ \\
\cline { 2 - 3 } & Calcite & $4.1[20]$ \\
\cline { 2 - 3 } Industrial byproducts & Limestone & $0.3[21]$ \\
\cline { 2 - 3 } & Slags & $2.0-2.3[22]$ \\
\cline { 2 - 3 } & Fly ash & $6.6[23]$ \\
\hline \multirow{3}{*}{ Modified/synthetic products } & Red mud & $7.2-75[23]$ \\
\cline { 2 - 3 } & Phoslock ${ }^{\circledR}$ & $50[25]$ \\
\cline { 2 - 3 } & AlgalBLOCK ${ }^{\circledR}$ & $25-55[24]$ \\
\cline { 2 - 3 } & BaraClear $^{\circledR}$ & \\
\hline
\end{tabular}

We previously developed an effective $\mathrm{P}$ adsorbent, lanthanum/aluminium hydroxide composite (LAH), which has a P adsorption capability 5-8 times higher than Phoslock ${ }^{\circledR}$ [26]. However, like other new $\mathrm{P}$ adsorbent demonstration experiments [27], the P adsorption capability has been tested in small-scale experiments using water samples with high $\mathrm{P}$ concentrations of $30 \mathrm{mg} / \mathrm{L}$ or above $[11,14]$. Equilibrium adsorption studies are often conducted under conditions with relatively long contact time (hours or days) [28]. Runoff and river water represent a great challenge for P removal due to their high volume and flow rate, which makes some bench-scale results hardly applicable under up-scaled field conditions.

In this study, the P recapture capability of the P adsorbent LAH, previously demonstrated to be superior in lab-scale batch experiments, was further evaluated in a simulated pilot-scale river-lake system. The inflow of the system was designed as a more realistic situation, with an inflow rate of 
$57 \mathrm{~L} /$ day and $\mathrm{P}$ concentration of $230 \mu \mathrm{g} / \mathrm{L}$. In order to achieve the strict target of $10 \mu \mathrm{g} \mathrm{P} / \mathrm{L}$ in natural waters, the concept of a combined approach of external $\mathrm{P}$ recapture by a $\mathrm{P}$ adsorbent column and further internal P removal inside the simulated lake (receiving tank) by directly applied adsorbent was investigated. Moreover, the feasibility of the LAH adsorbent for further implementation is discussed against other widely used $\mathrm{P}$ adsorbents. The study aimed to explore an effective $\mathrm{P}$ adsorbent and a promising strategy for eutrophication management.

\section{Materials and Methods}

\subsection{Experimental Setup}

Based on the concept of a combined approach of external-internal $\mathrm{P}$ adsorption, the simulated river-lake system (Figure 1) was set up with an inflow rate of $57 \mathrm{~L} /$ day for 14 days during the experiment. First, $0.8 \mathrm{~m}^{3}$ of simulated river water was flowed through the adsorption column $(\varnothing 4 \mathrm{~cm}$ and height $60 \mathrm{~cm}$ ) in order to test the external P-capturing treatment. The columns were filled with LAH-zeolite-coated adsorbent. The water/adsorbent contact time in the adsorbent columns was $16 \mathrm{~min}$ and the hydraulic loading rate was $45 \mathrm{~m} /$ day [29]. To simulate river water, the $P$ concentration of the influent was set at the level of $230 \mu \mathrm{g} / \mathrm{L}$ [9]. The effluent water passed through the column and then flowed into the receiving tank. The receiving tanks $\left(1 \mathrm{~m}^{3}\right)$ were made of PVC and glass (panel only) with the dimension of $1 \mathrm{~m} \times 1 \mathrm{~m} \times 1 \mathrm{~m}$ in length $\times$ height $\times$ width. Additional $\mathrm{P}$ adsorbent was placed in the receiving tanks for in-lake P capturing. The treatment systems were designed in duplicate, and another system without any LAH adsorbent was run as the control. The size of the tank for the control system was $0.375 \mathrm{~m}^{3}(0.5 \mathrm{~m} \times 0.5 \mathrm{~m} \times 1.5 \mathrm{~m})$ due to the unavailability of the same sized tank as was used with systems $\mathrm{A}$ and $\mathrm{B}$.

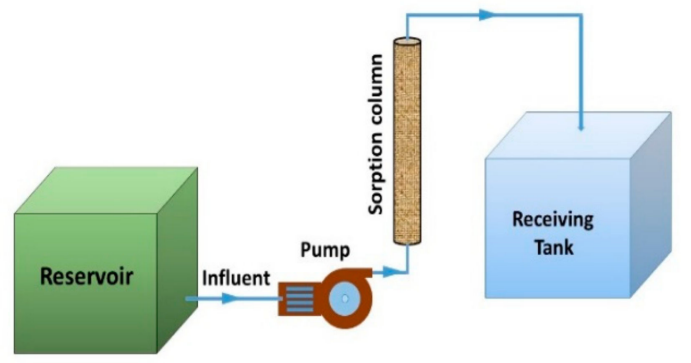

(a)

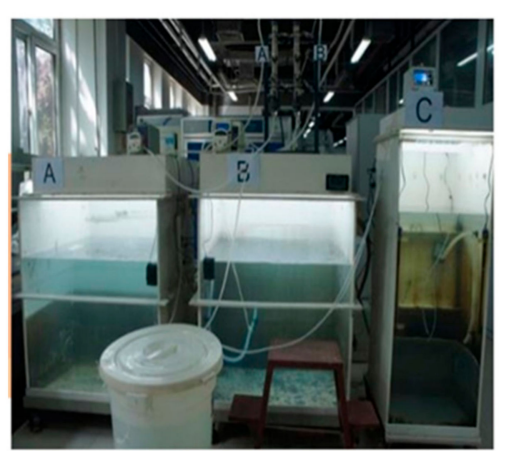

(b)

Figure 1. The conceptual arrangement (a) and picture (b) of the pilot scale experimental setup.

\subsection{P Adsorbents and Inflow Water Preparation}

The $\mathrm{LAH}$ adsorbent was prepared by precipitating lanthanum $(\mathrm{La})$ with aluminium $(\mathrm{Al})$ to obtain a La/Al hydroxide composite ( $5.3 \% \mathrm{La}$ ) following the procedure described by $\mathrm{Xu}$ [26]. In order to reduce the adsorbent loss through water flush in the column, the LAH adsorbent powders were coated onto zeolite particles $(\varnothing 0.5-1 \mathrm{~cm}$ ). In the adsorption column, $280 \mathrm{~g}$ of this modified adsorbent material (LAH mass percentage of 10.7\%) was employed. At the beginning of the experiment, $836 \mathrm{~g}$ of LAH-modified zeolite material was placed in the bottom of receiving tank (a total of $90 \mathrm{~g}$ of LAH adsorbent in $1 \mathrm{~m}^{3}$ water).

The simulated river water was prepared using tap water with a total phosphorus (TP) concentration of around $230 \mu \mathrm{g} / \mathrm{L}$. To achieve this concentration, $\mathrm{KH}_{2} \mathrm{PO}_{4}$ and $\mathrm{C}_{6} \mathrm{H}_{6} \mathrm{Na}_{12} \mathrm{O}_{24} \mathrm{P}_{6}$ (sodium phytate) were used, resulting in a composition of $87 \%$ inorganic and $13 \%$ organic P. Additionally, $\mathrm{NH}_{4} \mathrm{Cl}, \mathrm{NaNO}_{3}$, and $\mathrm{NaCl}$ were added and the ammonium, total nitrogen, and chloride concentrations were 0.65 , 12 , and $100 \mathrm{mg} / \mathrm{L}$, respectively. The experiment was conducted at room temperature (around $28^{\circ} \mathrm{C}$ ). 
Receiving tanks for the duplicated treatment groups were filled with $0.75 \mathrm{~m}^{3}$ tap water at the beginning of the experiment, while in the control system, the receiving tank was left empty as no further $\mathrm{P}$ adsorption treatment was applied.

\subsection{Sampling and Analysis}

Water samples from inflow water, adsorption column outflow, and receiving tanks in the duplicated treatment groups were collected every day. Under the same daily sampling campaign, only inflow and receiving tank water samples were taken for the control system. All water samples were collected in triplicate using $100 \mathrm{~mL}$ sterilized glass bottles and stored at $4{ }^{\circ} \mathrm{C}$ before being analyzed within $48 \mathrm{~h}$. The $\mathrm{pH}$ and electrical conductivity (EC) were measured using portable meters (Multi-Parameter Meter HQ40d, and Sension + EC5, HACH, Loveland, CO, USA). After sample digestion with potassium persulfate, the TP concentration was determined by the Mo-Sb anti-spectrophotometer method [30]. Meanwhile, the TN concentration was measured by ultraviolet spectrophotometry following a digestion by potassium persulfate [31].

\subsection{Adsorption Equilibrium Test}

To understand the effect of temperature on $\mathrm{P}$ adsorption equilibrium and the kinetics of the LAH adsorbent, adsorption isotherm experiments were conducted in $50 \mathrm{~mL}$ centrifuge tubes with $1 \mathrm{~g} / \mathrm{L}$ LAH suspensions at an ionic strength of $0.01 \mathrm{M} \mathrm{NaCl}$. A series of initial phosphate concentrations of $100,200,300,1000,3000,6000$, and 10,000 $\mu \mathrm{g} / \mathrm{L}$ were added and made up to a total volume of $30 \mathrm{~mL}$ in each tube. The centrifuge tubes were continually agitated for $24 \mathrm{~h}$ in a thermostatic shaker at $150 \mathrm{rpm}$ at different temperatures $\left(5,10,20\right.$, and $\left.30^{\circ} \mathrm{C}\right)$. After completion, the suspensions were collected and the $\mathrm{P}$ concentrations were determined. Adsorption data were fitted by the Freundlich isotherm model using the following equation [32]

$$
\mathrm{q}_{\mathrm{e}}=\mathrm{K}_{\mathrm{F}} \mathrm{C}_{\mathrm{e}}^{1 / \mathrm{n}}
$$

where $\mathrm{q}_{\mathrm{e}}$ is the amount of phosphate adsorbed on the solid phase $(\mathrm{mg} / \mathrm{g}), \mathrm{Ce}(\mathrm{mg} / \mathrm{L})$ is the equilibrium phosphate concentration, $\mathrm{K}_{\mathrm{F}}$ is the constant of the adsorption capacity, and $1 / \mathrm{n}$ is the constant of the intensity of adsorption.

\section{Results \& Discussion}

\subsection{External and Internal P Recapture}

In this study, the $\mathrm{P}$ concentrations of the outflow of the adsorption columns and in the receiving tanks decreased rapidly in the treatment systems (Figure 2a). However, the control system had no change in $\mathrm{P}$ concentration between the inflow and the effluent in the receiving tank. The P concentration of the adsorption column effluent decreased rapidly from $230 \mu \mathrm{g} / \mathrm{L}$ to around $20 \mu \mathrm{g} / \mathrm{L}$ in the first 2 days, and remained at this reduced level until Day 5. P concentrations then gradually increased until Day 14, reaching a concentration of approximately $100 \mu \mathrm{g} / \mathrm{L}$. Based on the mass balance calculation for $\mathrm{P}$, the adsorption was $56.1 \mathrm{mg} \mathrm{P} / \mathrm{g}$ LAH adsorbent at Day 14. Even though the previously demonstrated equilibrium P-adsorption capacity of LAH was $76.3 \mathrm{mg}$ P/g LAH in a batch experiment [26], the present study showed that the P-adsorption ability and rate was reduced around $25 \%$. The result agrees with the previous study that the column adsorption capacity for $\mathrm{P}$ could be negatively affected by high flow rate and low inflow $\mathrm{P}$ concentration [33]. The current flow rate $(57 \mathrm{~L} /$ day) was generally much higher than that in the reported column-mode studies [34]. Under such conditions, the adsorption capacity (56.1 mg P/g) still showed comparable value to other synthesized P adsorbents under the batch experiments. 

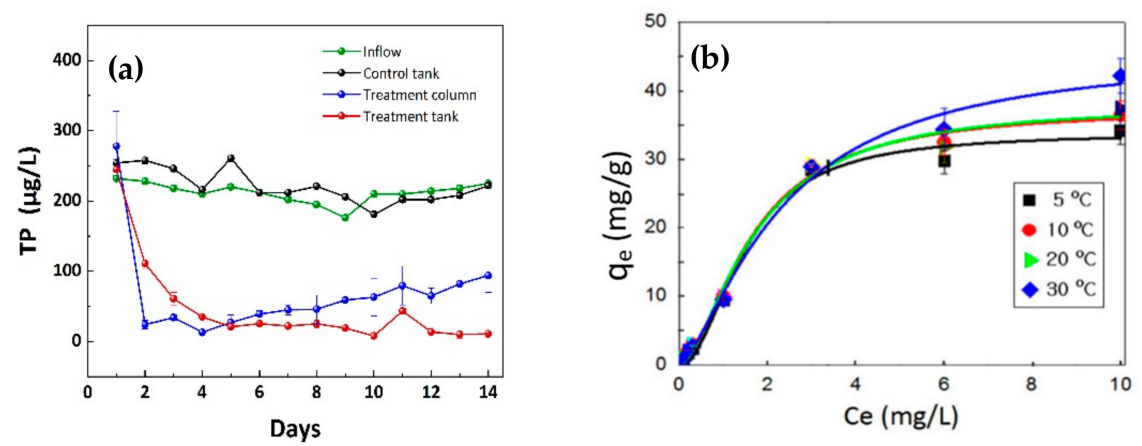

Figure 2. The dynamics of total phosphorus (TP) (a) in the inflow and outflow from the adsorption columns and tanks. (b) Freundlich adsorption isotherm fitting plots of phosphorus adsorption by LAH adsorbent.

The reduced P-adsorption ability may also have been due to the possibility of the LAH powder loss from the coated zeolite during water flushing. The majority of the synthetic $\mathrm{P}$ adsorbent consists of small particles; thus, the techniques used in a granulating process or one that is used to coat them onto a substrate are important for their effective retention in the adsorption columns [35]. In order for the field implementation of the LAH P adsorbent, it is important to optimize the granulation technique in the production of LAH adsorbent particles.

Geoengineered P adsorbent materials can be applied in situ in lakes for internal P recapture [36]; however, the target of $10 \mu \mathrm{g} / \mathrm{L}$ in the water could hardly be achieved by a single operation. Previous studies have reported that in-lake treatment by the application of a P adsorbent, such as modified zeolite, directly into the water, could only decrease the P concentration from $769 \mu \mathrm{g} / \mathrm{L}$ to $310 \mu \mathrm{g} / \mathrm{L}$ [37]. Phoslock ${ }^{\circledR}$, a synthesized $\mathrm{P}$ adsorbent, has been recommended at a dosage at $200 \mathrm{~g}$ adsorbent per $\mathrm{m}^{3}$ lake waters with an initial $100 \mu \mathrm{g} P / \mathrm{L}$ in order to reach the final P concentration of $10 \mu \mathrm{g} \mathrm{P} / \mathrm{L}$ [18]. In the present study, the simulated river water was first treated by the P-adsorption column and then subjected to further P recapturing in the receiving tank with $90 \mathrm{~g}$ LAH adsorbent per $\mathrm{m}^{3}$ water. The P concentration in the tank gradually decreased to $20 \mu \mathrm{g} / \mathrm{L}$ on Day 5 , and generally remained below $10 \mu \mathrm{g} / \mathrm{L}$ after Day 10 (Figure 2a). The results indicated that the highly effective LAH adsorbent could be used to successfully recapture ultra-low $\mathrm{P}$.

\subsection{P Equilibrium Adsorption Capacity and Potential Interaction with Water Quality}

Natural water body treatment of $\mathrm{P}$ usually requires long-term and stable performance under multi-environmental changes such as $\mathrm{pH}$ and temperature. A previous study investigated the effect of $\mathrm{pH}$ on $\mathrm{LAH}$ performance and indicated adsorption stability against $\mathrm{pH}$ changes between 4 and 10 [26]. In this study, the $P$ adsorption isotherm results (Figure $2 b$ ) fitted well with the Freundlich model ( $R^{2}$ range of 0.91 to 0.96 , Table 2$)$. The equilibrium achieved a stable $P$ adsorption capacity from 34 to $40 \mathrm{mg} \mathrm{P} / \mathrm{g}$, which supported that LAH adsorbent maintained a relatively stable P adsorption performance within the temperature range of $5-30{ }^{\circ} \mathrm{C}$. This may be due to the wide temperature stability of the $\mathrm{La}$ and $\mathrm{Al}$ hydroxide in $\mathrm{LAH}$, which could lead to a relatively stable positive charge of LAH surface to attract the negatively charged $\mathrm{PO}_{4}{ }^{3-}$ [26]. Comparatively, the P adsorption capacity of Phoslock ${ }^{\circledR}$ can be significantly inhibited by low environmental temperatures [38]. The stable performance of the LAH adsorbent indicated long-term P adsorption effectiveness and a wider application than P adsorbents that can be easily affected by temperature fluctuation.

Figure 3a shows the similar $\mathrm{pH}$ values $(p>0.05)$ between the tank outflow (range of 7.6-8.0) and the inflow $(\mathrm{pH}=7.5)$, which support the idea that the LAH adsorbent exhibited limited aquatic environmental disturbance. Besides $\mathrm{P}$, the accumulation of nutrient $\mathrm{N}$ in water is also a significant factor that could cause water eutrophication [39]. In this study, TN concentrations generally remained at the same level (average of $12 \mathrm{mg} / \mathrm{L}$ ) throughout the experiment (Figure 3b). This result agrees with 
the previous study on $\mathrm{LAH}$, where the adsorbent had slight or no significant effect on the concentration of $\mathrm{N}$ [26]. When considering future engineering applications, improvements in coating materials could be made so that $\mathrm{N}$ may be removed simultaneously. For example, materials such as resins could be considered as a coating material, instead of zeolite, which may provide an additional function for $\mathrm{N}$ removal [40].

Table 2. Freundlich isotherm nonlinear curve fit parameters.

\begin{tabular}{cccc}
\hline Temperatures & $\mathbf{q}_{\mathbf{e}}=\mathbf{k C}_{\mathbf{e}}{ }^{\mathbf{1}} \mathbf{1} \mathbf{n}$ & Standard Error & $\mathbf{R}^{\mathbf{2}}$ \\
\hline \multirow{2}{*}{$5{ }^{\circ} \mathrm{C}$} & $\mathrm{k}=16.8$ & 2.39 & 0.96 \\
& $1 / \mathrm{n}=0.41$ & 0.49 & \\
\hline \multirow{2}{*}{$10^{\circ} \mathrm{C}$} & $\mathrm{k}=22.4$ & 4.89 & \multirow{2}{*}{0.91} \\
& $1 / \mathrm{n}=0.29$ & 1.56 & \\
\hline \multirow{2}{*}{$20^{\circ} \mathrm{C}$} & $\mathrm{k}=21.7$ & 2.35 & 0.96 \\
& $1 / \mathrm{n}=0.31$ & 0.61 & \\
\hline \multirow{2}{*}{$30^{\circ} \mathrm{C}$} & $\mathrm{k}=20.1$ & 2.69 & \multirow{2}{*}{0.96} \\
\hline
\end{tabular}
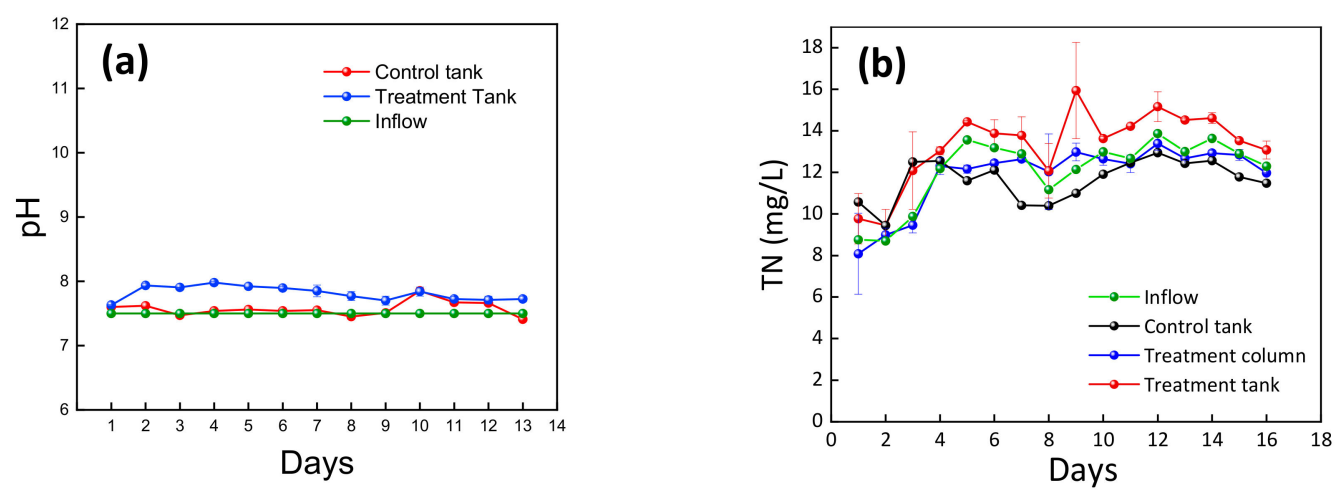

Figure 3. The dynamics of $\mathrm{pH}(\mathbf{a})$ and total nitrogen (TN) (b) in the inflow and outflow from the adsorption columns and tanks.

Notably, in real applications adsorbents will always be affected by the comprehensive surrounding factors, e.g., sediment, organism, vegetation, etc. As the first scaled-up study, this investigation focused on stoichiometric capacity, regardless of the complexity mentioned before. The results revealed the stable and high stoichiometric P-adsorption capacity of the LAH in a pilot study, which will be the foundation for further development into real applications. Synthetic investigations including sediment, organisms, and vegetation in lakes should also be conducted in further research.

\subsection{Implementation Feasibility}

The current study demonstrated the high P adsorption capacity of the LAH adsorbent under a realistic inflow rate and $\mathrm{P}$ concentration. Such adsorption ability could, in turn, decrease the applied dosage, which might contribute to a reduced cost for practice and La release potential. Currently, $P$ adsorbents are often directly applied into water bodies for in situ P recapture. This study demonstrated that inducing runoff or river water flow through a P-adsorbent column can achieve significant $\mathrm{P}$ removal externally on land prior to the internal $\mathrm{P}$ recapture. Moreover, the P desorption of the LAH was reported in a previous study with a rate of $0.22 \%-4.05 \%$ when the $\mathrm{pH}$ changed within 4 to 8.5 [26]. The coated material improved the LAH from powder shape into granules, which makes the recycling and reutilisation of the adsorbent after desorption possible. 


\section{Conclusions}

A pilot-scale system was used to simulate a river-lake system from the stoichiometric standpoint and to evaluate the approach for eutrophication control regardless of sediment, biology, and other environmental factors, based on the concept of combined external $\mathrm{P}$ removal from river water and internal P recapture from receiving lakes. After the treatment with the P-adsorption column equipped with the LAH adsorbent and direct application of LAH adsorbent into receiving tanks, the final $\mathrm{P}$ concentration could be reduced from $230 \mu \mathrm{g} / \mathrm{L}$ to below $10 \mu \mathrm{g} / \mathrm{L}$. The synergy of external and internal phosphorus recapture proved to be an effective strategy for potential eutrophication management under mesotrophic $\mathrm{P}$ waters input. The results also demonstrated that the application of LAH adsorbent could reduce the cost for geoengineering for eutrophication management. Further research before application should be conducted, considering the synthetic effect of sediment, organisms, and vegetation in lakes.

Author Contributions: Conceptualization and supervision, G.P.; Investigation, L.B., L.W., H.Z., M.Z., J.C., C.Y., J.A.; Writing-Original Draft, M.P.; Writing—Review\&Editing, T.L., S.B., N.R. and G.P. All authors have read and agreed to the published version of the manuscript.

Funding: This research was funded by the National Key Research and Development Program of China, grant number [2017YFA020724] and the Proof of Concept (POC) project at Nottingham Trent University. The PhD fellowship of Minmin Pan was supported by the China Scholarship Council (CSC).

Acknowledgments: Chen Liu, Ying Tang, Qing Xu, Xiaonan Ji, Xiaoguang Jin, Jing Su, Wanchun Zhang, Kaiqi Wang, Chen Wang and Mick Cooper are acknowledged for their valuable assistance with the experiment conduction, data analysis, and language improvement.

Conflicts of Interest: The authors declare no conflict of interest.

\section{References}

1. Elser, J.; Bennett, E. Phosphorus cycle: A broken biogeochemical cycle. Nature 2011, 478, 29-31. [CrossRef] [PubMed]

2. Van Vuuren, D.P.; Bouwman, A.F.; Beusen, A.H.W. Phosphorus demand for the 1970-2100 period: A scenario analysis of resource depletion. Glob. Environ. Chang. 2010, 20, 428-439. [CrossRef]

3. Peñuelas, J.; Poulter, B.; Sardans, J.; Ciais, P.; Velde, M.; Bopp, L.; Boucher, O.; Godderis, Y.; Hinsinger, P.; Llusia, J.; et al. Human-induced nitrogen-phosphorus imbalances alter natural and managed ecosystems across the globe. Nat. Commun. 2013, 4, 2934. [CrossRef] [PubMed]

4. Pan, G.; Lyu, T.; Mortimer, R. Comment: Closing phosphorus cycle from natural waters: Re-capturing phosphorus through an integrated water-energy-food strategy. J. Environ. Sci-China 2018, 65, 375-376. [CrossRef] [PubMed]

5. Richardson, C.J.; King, R.S.; Qian, S.S.; Vaithiyanathan, P.; Qualls, R.; Stow, C.A. Estimating ecological thresholds for phosphours in the everglades. Environ. Sci. Technol. 2007, 41, 8084-8091. [CrossRef]

6. Carvalho, L.; McDonald, C.; Hoyos, C.D.; Mischke, U.; Phillips, G.; Borics, G.; Poikane, S.; Skjelbred, B.; Solheim, A.L.; Wichelen, J.V.; et al. Sustaining recreational quality of European lakes: Minimizing the health risks from algal blooms through phosphorus control. J. Appl. Ecol. 2013, 50, 315-332. [CrossRef]

7. Khare, Y.; Naja, G.M.; Stainback, G.A.; Martinez, C.J.; Paudel, R.; van Lent, T. A Phased Assessment of Restoration Alternatives to Achieve Phosphorus Water Quality Targets for Lake Okeechobee, Florida, USA. Water 2019, 11, 327. [CrossRef]

8. Dierberg, F.E.; DeBusk, T.A.; Jackson, S.D.; Chimney, M.J.; Pietro, K. Submerged aquatic vegetation-based treatment wetlands for removing phosphorus from agricultural runoff: Response to hydraulic and nutrient loading. Water Res. 2002, 36, 1409-1422. [CrossRef]

9. Grenon, G.; Madramootoo, C.A.; Singh, B.; Gaj, N. Water Quality Management in the Holland Marsh, Ontario; ASABE Annual International Meeting; American Society of Agricultural and Biological Engineers: St. Joseph, MI, USA, 2016; p. 1.

10. United States Environmental Protection Agency (U.S. EPA). Nutrient Criteria Technical Guidance Manual, Lakes and Reservoirs; Office of Science and Technology: Washington, DC, USA, 2000; p. 822. Available online: https://www.epa.gov/nutrient-policy-data/criteria-development-guidance-lakes-and-reservoirs (accessed on 20 June 2000). 
11. Genz, A.; Kornmüller, A.; Jekel, M. Advanced phosphorus removal from membrane filtrates by adsorption on activated aluminium oxide and granulated ferric hydorxide. Water Res. 2004, 38, 3523-3530. [CrossRef]

12. Zhu, X.P.; Jyo, A. Column-mode phosphate removal by a novel highly selective adsorbent. Water Res. 2005, 39, 2301-2308. [CrossRef]

13. Kumar, P.S.; Korving, L.; van Loosdrecht, M.C.M.; Witkamp, G.J. Adsorption as a technology to achieve ultra-low concentrations of phosphate: Research gaps and economic analysis. Water Res. X 2019, 4, 100029. [CrossRef] [PubMed]

14. Bhadha, J.H.; Jennewein, S.P.; Khatiwada, R. Phosphorus Sorption Behavior of Torrefied Agricultural Byproducts under Sonicated Versus Non-Sonicated Conditions. Sustain. Agric. Res. 2017, 6, 4. [CrossRef]

15. Zhou, M.F.; Li, Y.C. Phosphorus-sorption characteristics of calcareous soils and limestone from the southern everglades and adjacent farmlands. Soil Sci. Soc. Am. J. 2000, 65, 1404-1412. [CrossRef]

16. Proctor, D.; Fehling, K.; Shay, E.; Wittenborn, J.; Green, J.; Avent, C.; Bigham, R.; Connolly, M.; Lee, B.; Shepker, T. Physical and chemical characteristics of blast furnace, basic oxygen furnace, and electric arc furnace steel industry slags. Environ. Sci. Technol. 2000, 34, 1576-1582. [CrossRef]

17. Lürling, M.; Waajen, G.; van Oosterhout, F. Humic substances interfere with phosphate removal by lanthanum modified clay in controlling eutrophication. Water Res. 2014, 54, 78-88. [CrossRef]

18. Reitzel, K.; Andersen, F.; Egemose, S.; Jensen, H.S. Phosphate adsorption by lanthanum modified bentonite clay in fresh and brackish water. Water Res. 2013, 47, 2787-2796. [CrossRef]

19. Kim, D.; Ryoo, K.S.; Hong, Y.P.; Choi, J.H. Evaluation of loess capability for adsorption of total nitrogen (T-N) and total phophorous (T-P) in aqueous solution. Bull Korean Chem. Soc. 2014, 35, 2471-2476. [CrossRef]

20. Molle, P.; Lienard, A.; Grasmick, A.; Iwema, A. Phosphorus retention in subsurface constructed wetlands: Investigations focused on calcareous materials and their chemical reactions. Water Sci. Technol. 2003, 48, 75-83. [CrossRef]

21. Drizo, A.; Frost, C.A.; Grace, J.; Smith, K.A. Physico-chemical screening of phosphate-removing substrates for use in constructed wetland systems. Water Res. 1999, 33, 3595-3602. [CrossRef]

22. Drizo, A.; Forget, C.; Chapuis, R.P.; Comeau, Y. Phosphorus removal by electric arc furnace steel slag and serpentinite. Water Res. 2006, 40, 1547-1554. [CrossRef]

23. Wang, Y.; Yu, Y.G.; Li, H.Y.; Shen, C.C. Comparison study of phosphorus adsorption on different waste solids: Fly ash, red mud and ferric-alum water treatment residues. J. Environ. Sci.-China. 2016, 50, 79-86. [CrossRef] [PubMed]

24. Svatos, K.B. Commercial silicate phosphate sequestration and desorption leads to a gradual decline of aquatic systems. Environ. Sci. Pollut. Res. 2018, 25, 5386-5392. [CrossRef] [PubMed]

25. Gonçalves, M.A.S.C. New Eco-Efficient Polymers for Phosphorus Recovery; Universidade do Minho-Campus de Gualtar: Braga, Portugal, 2012; Available online: https://search.proquest.com/docview/1900972696?pqorigsite $=$ gscholar (accessed on 1 April 2012).

26. Xu, R.; Zhang, M.; Mortimer, R.J.; Pan, G. Enhanced phosphorus locking by novel lanthanum/aluminumhydroxide composite: Implications for eutrophication control. Environ. Sci. Technol. 2017, 51, 3418-3425. [CrossRef]

27. Iizuka, A.; Sasaki, T.; Hongo, T.; Honma, M.; Hayakawa, Y.; Yamasaki, A.; Yanagisawa, Y. Phosphorus adsorbent derived from concrete sludge (PAdeCS) and its phosphorus recovery performance. Ind. Eng. Chem. Res. 2012, 51, 11266-11273. [CrossRef]

28. Yin, H.; Kong, M. Simultaneous removal of ammonium and phosphate from eutrophic waters using natural calcium-rich attapulgite-based versatile adsorbent. Desalination 2014, 351, 128-137. [CrossRef]

29. Hsieh, C.H.; Davis, A.P.; Needelman, B.A. Bioretention column studies of phosphorus removal from urban stormwater runoff. Water Environ. Res. 2007, 79, 177-184. [CrossRef]

30. Fu, X.Y.; Cui, G.Y.; Huang, K.; Chen, X.M.; Li, F.S.; Zhang, X.Y.; Li, F. Earthworms facilitate the stabilization of pelletized dewatered sludge through shaping microbial biomass and activity and community. Environ. Sci. Pollut. Res. 2016, 23, 4522-4530. [CrossRef]

31. Ding, Z.B.; Yu, Z.H.; Cheng, T.T.; Zhang, P.; Gao, X. Research on experimental condition of analysing total nitrogen of water by ultraviolet spectrophotometric method. Water Purif. Technol. 2008, 27, 61-64. Available online: http://en.cnki.com.cn/Article_en/CJFDTotal-ZSJS200801018.htm (accessed on 25 January 2008).

32. Pang, G.; Liss, P.S. Metastable-equilibrium adsorption theory. J. Colloid Interface Sci. 1998, 201, 71-76. 
33. Xing, X.; Gao, B.; Wang, W.; Yue, Q.; Wang, Y.; Ni, S. Adsorption of phosphate from aqueous solutions onto modified wheat residue: Characteristics, kinetic and column studies. Colloid Surface B 2009, 70, 46-52.

34. Han, R.; Wang, Y.; Zou, W.; Wang, Y.; Shi, J. Comparison of linear and nonlinear analysis in estimating the Thomas model parameters for methylene blue adsorption onto natural zeolite in fixed-bed column. J. Hazard. Mater. 2007, 145, 331-335. [CrossRef]

35. Douglas, G.; Hamilton, D.; Robb, M.; Pan, G.; Spears, B.M.; Lurling, M. Guiding principles for the development and application of solid-phase phosphorus adsorbents for freshwater ecosystems. Aquat. Ecol. 2016, 50, 385-405. [CrossRef]

36. Robb, M.; Greenop, B.; Goss, Z.; Douglas, G.; Adeney, J. Application of Phoslock, an innovative phosphorus binding clay, to two Western Australian waterways: Preliminary findings. Hydrobiologia 2003, 494, 237-243. [CrossRef]

37. Ozkundakci, D.; Hamilton, D.P.; Scholes, P. Effect of intensive catchment and in-lake restoration procedures on phosphorus concentrations in a eutrophic lake. Ecol. Eng. 2010, 36, 396-405. [CrossRef]

38. Haghseresht, F.; Wang, S.; Do, D.D. A novel lanthanum-modified bentonite, Phoslock, for phosphate removal from wastewaters. Appl. Clay Sci. 2009, 46, 369-375. [CrossRef]

39. Conley, D.J.; Paerl, H.W.; Howarth, R.W.; Boesch, D.F.; Seitzinger, S.P.; Havens, K.E.; Lancelot, C.; Likens, G.E. Controlling eutrophication: Nitrogen and phosphorus. Science 2009, 323, 1014-1015. [CrossRef]

40. Langlois, J.L.; Johnson, D.W.; Mehuys, G.R. Adsorption and recovery of dissolved organic phosphorus and nitrogen by mixed-bed ion-exchange resin. Soil. Sci. Soc. Am. J. 2003, 67, 889-894. [CrossRef]

(C) 2019 by the authors. Licensee MDPI, Basel, Switzerland. This article is an open access article distributed under the terms and conditions of the Creative Commons Attribution (CC BY) license (http://creativecommons.org/licenses/by/4.0/). 